\title{
Stable isotope tracing of links between marine wintering and freshwater breeding habitats of Red-necked Grebes
}

\author{
Janusz Kloskowski ${ }^{1}$ (1) $\cdot$ Andrzej Trembaczowski $^{2} \cdot$ Maciej Filipiuk $^{3}$
}

Received: 19 November 2018 / Revised: 3 January 2019 / Accepted: 15 February 2019 / Published online: 28 February 2019

(c) The Author(s) 2019

\begin{abstract}
Stable isotope analyses can detect interactions between different stages of the annual cycle in migratory animals. We used carbon $\left(\delta^{13} \mathrm{C}\right)$, nitrogen $\left(\delta^{15} \mathrm{~N}\right)$ and sulphur $\left(\delta^{34} \mathrm{~S}\right)$ isotopes to identify non-breeding environments, the strategy of nutrient allocation to eggs, and potential carry-over effects from wintering areas in Red-necked Grebes Podiceps grisegena breeding in eastern Poland. Strongly positive isotopic signatures in adult grebe feathers compared to freshwater food webs and feathers of locally fledged young suggested that most adults had moulted in marine areas. Enriched isotopic values in the breast muscles of spring-arriving grebes pointed to transfer of marine-derived nutrients to freshwater breeding sites. Isotopic mixing models revealed that egg nutrients were mainly acquired locally. Endogenous nutrients were to some extent mobilised for the formation of albumen (25-26\%, 95\% credible interval, three-isotope model) and lipid-free yolk (17-18\%, two-isotope, $\delta^{13} \mathrm{C}$ and $\delta^{15} \mathrm{~N}$ model) in early laid clutches, but were little mobilised, if at all, in clutches of females that delayed laying. The non-breeding trophic feeding level, as indexed by $\delta^{15} \mathrm{~N}$ in feathers of grebe females, was related to laying initiation date (greater enrichment, earlier egg production), indicating cross-seasonal effects on reproduction. Both endogenous nutrient transfer to eggs and a high-quality non-breeding diet may facilitate early breeding, which is advantageous in species constrained by short breeding seasons.
\end{abstract}

Keywords Carry-over effects $\cdot$ Ecological connectivity $\cdot$ Mixing models $\cdot$ Moult $\cdot$ Reproductive investment

\section{Zusammenfassung}

Stabile Isotope zeigen Zusammenhänge zwischen marinen Überwinterungs- und limnischen Brutgebieten beim Rothalstaucher (Podiceps grisegena).

Anhand von Analysen stabiler Isotope kann man Wechselwirkungen zwischen den unterschiedlichen Stadien des Jahresrhythmus von Zugvögeln aufspüren. Wir benutzten Kohlenstoff-, Stickstoff- und Schwefel-Isotope, um Gebiete außerhalb der Brutzeit, die Strategie der Nährstoffzufuhr in die Eier und mögliche Übertragungseffekte aus den Wintergebieten bei in Ost-Polen brütenden Rothalstauchern (Podiceps grisegena) herauszufinden. Ausgeprägt positive Isotopensignaturen in den Federn adulter Rothalstaucher im Vergleich zu den Süßwasser-Nahrungsketten und Federn der vor Ort geschlüpften Jungvögel legten nahe, dass die meisten adulten Vögel in marinen Gebieten gemausert hatten. Angereicherte Isotopenkonzentrationen in den Brustmuskeln der im Frühjahr eingetroffenen Rothalstaucher wiesen auf einen Transport von Nährstoffen aus dem Meer zu den Süßwasserbrutgebieten hin. Isotopische Misch-Modelle zeigten, dass die in den Eiern vorkommenden Nährstoffe in erster Linie lokalen Ursprungs waren. Körpereigene Nährstoffe wurden bei frühen Gelegen zu einem gewissen Anteil zum Aufbau von Eiweiß (25-26\%; 95\%-Vertrauensintervall, Drei-Isotopen-Modell) und fettfreiem Eigelb mobilisiert (17-18\%, Zwei-Isotopen-Modell, $\delta^{13} \mathrm{C}$ und $\left.\delta^{15} \mathrm{~N}\right)$. Bei spät begonnenen Gelegen wurden körpereigene Reserven nur sehr selten oder gar nicht mobilisiert. Die trophische Nahrungsaufnahme außerhalb der Brutzeit, angezeigt durch $\delta^{15} \mathrm{~N}$ in Federn der Weibchen, hing mit dem Beginn der Eiablage (größere Anreicherung, frühere Eiproduktion) zusammen, was Übertragungseffekte auf die Fortpflanzung anzeigt. Sowohl die körpereigene Verlagerung von Nährstoffen

Communicated by N. Chernetsov.

Extended author information available on the last page of the article 
in die Eier als auch eine qualitativ hochwertige Nahrung außerhalb der Brutzeit kann das Brüten zu einem frühen Zeitpunkt erleichtern, was wiederum für Arten, die durch eine kurze Brutsaison eingeschränkt sind, von Vorteil ist.

\section{Introduction}

Stable isotopes can be used as ecological tracers of diet because their concentrations vary naturally in response to ecological and environmental factors (Peterson and Fry 1987). The levels of stable isotopes incorporated into consumer tissues persist over varying time periods, depending on the tissue-specific dynamics of nutrient storage [isotopic tissue turnover rate (Tieszen et al. 1983)], and thus the information obtained from isotope data can be examined at different temporal scales (Schmaltz et al. 2018). Certain tissues, such as feathers, once grown become metabolically inert, and their chemical composition reflects the environment and diet at the time of growth. Stable isotope ratios of carbon $\left({ }^{13} \mathrm{C} /{ }^{12} \mathrm{C} ; \delta^{13} \mathrm{C}\right)$ and sulphur $\left({ }^{34} \mathrm{~S} /{ }^{32} \mathrm{~S}\right.$; $\delta^{34} \mathrm{~S}$ ) enable delineation between the sources of primary production; they typically change little as the elements pass through the food web (Michener and Schell 1994; Croisetière et al. 2009; but see Hart and Lovvorn 2002; McCutchan et al. 2003). The utility of stable isotopes of nitrogen $\left({ }^{15} \mathrm{~N} /{ }^{14} \mathrm{~N} ; \delta^{15} \mathrm{~N}\right)$ in ecological investigations is based on the net loss of ${ }^{14} \mathrm{~N}$ in nitrogenous waste; progressive enrichment of $2-5 \%$ in ${ }^{15} \mathrm{~N}$ occurs across trophic levels (Minagawa and Wada 1984; McCutchan et al. 2003). Thus, $\delta^{15} \mathrm{~N}$ signatures help to define trophic relationships among food web components (Minagawa and Wada 1984; Peterson and Fry 1987). Generally, isotopic ratios from marine ecosystems are enriched for $\delta^{13} \mathrm{C}, \delta^{15} \mathrm{~N}$ and $\delta^{34} \mathrm{~S}$ relative to freshwater ecosystems (Fry and Sherr 1989; Michener and Schell 1994); therefore marine-produced dietary nutrients have more positive isotopic ratios than freshwater nutrients. Owing to contrasting isotopic ratios between sources of $\mathrm{C}$ fixed in marine and freshwater food chains, tissues of marine animals are typically $7 \%$ more positive for $\delta^{13} \mathrm{C}$ than those from their inland counterparts (Chisholm et al. 1982). $\delta^{34} \mathrm{~S}$, relatively infrequently used as an ecological tracer, is also informative due to the considerable disparities in ${ }^{34} \mathrm{~S}$ signals between marine and freshwater sulphates (Peterson and Fry 1987; Lott et al. 2003). Thus, animals using both freshwater and marine environments in their annual cycle are amenable to isotopic tracking of connectivity between seasons, including the origin of nutrients used for reproduction (e.g. Hobson et al. 1997; Langin et al. 2006; Hahn et al. 2011), and assessment of how events during the non-breeding period carry over into subsequent breeding performance (Marra et al. 1998).
Waterbirds are a popular model for studying links between non-breeding and breeding grounds. In environments where food is seasonally limited and egg production can be energetically and nutritionally challenging, migratory waterbirds exhibit a variety of strategies for meeting the expenses of clutch production (Alisauskas and Ankney 1992). Most species rely on locally available exogenous dietary resources for egg formation (income breeding); alternatively, birds can mobilise endogenous reserves accumulated earlier (capital breeding) (Drent and Daan 1980; Janke et al. 2015). Recent studies have questioned the occurrence of pure capital breeding; however, many species use an intermediate strategy, relying to some degree on endogenous stores for egg formation (e.g. Gauthier et al. 2003; Oppel et al. 2010; Sénéchal et al. 2011). Since females need to accumulate adequate nutrient reserves for breeding, the timing of reproduction is likely to be constrained by a female's condition and her diet during the pre-breeding period (Bêty et al. 2003; Sorensen et al. 2009). Birds able to exploit a high-quality diet during winter are likely to have greater nutrient reserves and thus attain breeding condition earlier in the spring and produce larger eggs (Lehikoinen et al. 2006; Sorensen et al. 2009). In many species these traits are associated with higher reproductive performance and post-hatching chick survival rates (Blomqvist et al. 1997; Sydeman et al. 1991).

In contrast to the relatively well-studied Anseriformes (reviewed in Klaassen et al. 2006), waterfowl that typically use both aquatic and terrestrial habitats, we know little about the cross-seasonal effects of non-breeding conditions and nutrient investment strategies in taxa such as grebes (Podicipediformes) or divers (Gaviiformes), whose entire life cycle is confined to aquatic habitats, making data collection more demanding [but see Paszkowski et al. (2004) and studies on sea ducks (e.g. Lehikoinen et al. 2006; DeVink et al. 2011)]. Our object of study was the Red-necked Grebe Podiceps grisegena, a medium-sized, monogamous, typically singlebrooded, territorial generalist predator nesting on shallow freshwater bodies. In Europe, Red-necked Grebes winter primarily in shallow marine or estuarine waters along the Baltic and North Sea coasts (Skov et al. 2011), where they presumably moult as well (Vlug 2018; J. Bellebaum, unpublished data). Adult birds are believed to undergo complete post-breeding moult in late summer and autumn, while the head and body plumage and some wing coverts are moulted prior to spring migration (Baker 1993; Vlug 2018). Rednecked Grebe populations have declined in certain parts of 
Europe; regional trends in annual survival may be related to conditions on the non-breeding grounds (Skov et al. 2011; Bellebaum et al. 2018). Our objectives were (1) to identify the nature of the isotopic landscape in which Red-necked Grebes moult their feathers; (2) to elucidate this species' strategy of nutrient allocation to reproduction [we expected that grebes would primarily derive nutrients for egg formation from exogenous sources (Paszkowski et al. 2004), although the short breeding period and low predictability of food supplies available during egg-laying (Kloskowski 2012) could favour mobilisation of endogenous reserves (Klaassen et al. 2006; Hahn et al. 2011)]; and (3) to examine the prediction that non-breeding diet quality affects the timing of breeding and egg size in Red-necked Grebes.

We analysed $\delta^{13} \mathrm{C}, \delta^{15} \mathrm{~N}$ and $\delta^{34} \mathrm{~S}$ in Red-necked Grebe feathers, muscles and egg constituents collected at different stages of the breeding season and in freshwater food sources. We also gathered data on the breeding performance (clutch initiation date and egg size) of the sampled females. To make inferences on the character of the non-breeding grounds, we compared $\delta^{13} \mathrm{C}$ values in adult feathers as tissues grown on the wintering grounds and in feathers of juvenile birds close to fledging. Birds with $\delta^{13} \mathrm{C}$ values $>-20 \%$ (Fry and Sherr 1989) and $\delta^{34} S$ values $>10 \%$ (Lott et al. 2003) were considered to have moulted in marine habitats. We assumed that isotopic values in non-inert tissues, such as muscles, reflected food webs of non-breeding areas when collected from newly arrived birds. To examine the origins of nutrients used for reproduction, we analysed the relative contribution of endogenous and local resources to egg components using Bayesian mixing models. If egg formation is largely supported by nutrients accumulated on marine non-breeding grounds, isotopic values in yolk and albumen should be related to the isotopic signatures of endogenous nutrient sources (here represented by the muscles of birds that arrive early). They should also be more positive in clutches laid soon after arrival at the breeding sites than in clutches of females that arrived early but delayed laying (Hobson et al. 1997; Morrison and Hobson 2004; see also Langin et al. 2006). Finally, we assumed that $\delta^{15} \mathrm{~N}$ levels in the feathers of breeding females are indicative of prey trophic level during feather growth and thus of diet quality (Becker et al. 2007) during the non-breeding period.

\section{Methods}

\section{Study area and population}

The field research was part of a larger study on Red-necked Grebes breeding on semi-natural ponds used for the extensive culture of Common Carp Cyprinus carpio in the vicinity of Lublin, eastern Poland $\left(51^{\circ} 18^{\prime}-27^{\prime} \mathrm{N}, 22^{\circ} 16^{\prime}-25^{\prime} \mathrm{E}\right)$.
The breeding ponds, distributed in loose clusters $10-50 \mathrm{~km}$ apart, mimicked natural shallow temporary waters because they were drained in winter. The ponds were uniform in depth (mean depth range $0.8-1.2 \mathrm{~m}$ ) and thus entirely littoral. Grebes established 'early' territories from mid-April to mid-May. Clutches usually contained 3-5 eggs. Breeding was highly asynchronous; egg-laying occasionally commenced in late April but typically in May. Second (replacement) clutches were laid by early July (Kloskowski 2001). We found and revisited nests during the laying and incubation period to determine laying dates, final clutch size, and egg size. If more than one new egg was present during a nest check, the laying sequence was established according to the degree of shell darkening. Eggs were individually marked and measured with callipers to the nearest $0.1 \mathrm{~mm}$; the volume index was calculated after Hoyt (1979).

\section{Sample collection and preparation}

Tissue samples were collected during breeding seasons from 1997 to 2013. Underwing innermost secondary median coverts were obtained from adult grebes and young close to fledging that had been trapped in underwater nets or captured by night lighting. Captured birds were individually ringed, measured for basic morphometric data, and sexed by DNA from small blood samples (Kloskowski et al. 2006). We also sampled, when intact, breast muscles and feathers from the back of the head, breast, primaries, median coverts, and underwing secondary median coverts of 12 adult birds (seven females and five males, four of them ringed as breeders in previous years) collected after sudden death (i.e. power line casualties, predation on incubating adults, accidental drowning in nets). Carcasses were collected throughout the breeding period (two females and one male apparently died upon their spring arrival between 21 and 24 April after colliding with power lines over the ponds, while the two birds collected last were predated on their nests in mid-June). All birds appeared in good condition. Apart from the three birds that died immediately upon arrival, all sampled dead or living adults were territorial nesters from at least early May, i.e. they had arrived at similar times. We assumed that the grebes had moulted the innermost underwing coverts in the pre-breeding period, along with the head and breast feathers (Baker 1993; Vlug 2018); this was indirectly corroborated by uniform $\delta^{13} \mathrm{C}$ signatures in feathers from these body regions, although we cannot rule out that the coverts were replaced in autumn (see Results).

Throughout May, i.e. the early breeding season, we collected eggs from presumed first clutches. Pairs from which eggs were taken had been observed in their territories from early May. Eggs were opportunistically collected within a few days of the start of incubation, salvaged when fallen from the nest platform or the nest was destroyed. Embryos 
had not started development in any of the analysed eggs. We used only one egg per nest, the first or second laid (the laying sequence was occasionally uncertain). Within-clutch difference could be important if endogenous nutrient input changes with laying order (Schmutz et al. 2006; Sénéchal et al. 2011).

To assess pond food web isotopic signatures, grebe prey were caught using activity traps and dip nets. Since baseline isotopic values (Vander Zanden and Rasmussen 1999) could vary locally, to obtain sample sizes balanced across study sites, samples for each prey type were distributed roughly evenly among the ponds (no more than one sample per pond) where dead birds and eggs were collected. Live birds were captured for sampling on the same or closely adjacent ponds. We identified the major dietary items of grebes during the early breeding season by examination of alimentary tracts, behavioural observations, and isotopic mixing models (Kloskowski and Trembaczowski 2015), and assigned these prey taxa to four categories: adult beetles (Coleoptera; individuals $>1 \mathrm{~cm}$ body length), aquatic leaf beetles (Donaciinae), Common Carp, and adult anurans breeding in the ponds (Table 1). Whole body homogenates of prey invertebrates were used for analyses. In fish and amphibians, white muscles were utilised because they are less variable in $\delta^{13} \mathrm{C}$ and $\delta^{15} \mathrm{~N}$ than other tissue types (Pinnegar and Polunin 1999). Prey samples, grebe muscles and eggs were rinsed in distilled water, wrapped in aluminium foil, and kept frozen at $-18^{\circ} \mathrm{C}$ within $6 \mathrm{~h}$ of collection, and later dried to constant mass in a drying oven. Yolk and albumen were separated while frozen. Feathers were individually stored in envelopes at room temperature. Later they were cut into small fragments, cleaned with acetone and ethyl alcohol to remove external contamination, and air dried.

The isotopic composition of albumen samples largely reflects the origin of proteins, while yolk contains a large amount of lipids as well. Lipid removal reduces $\delta^{13} \mathrm{C}$ heterogeneity in the samples, which is caused by faster ${ }^{13} \mathrm{C}$ turnover in lipids than in proteins and by lipid content variability (McConnaughey and McRoy 1979; Tieszen et al. 1983), but may alter $\delta^{15} \mathrm{~N}$ values (Pinnegar and Polunin 1999). Therefore, powdered individual samples were divided into subsamples. In the subset for $\delta^{15} \mathrm{~N}$ and $\delta^{34} \mathrm{~S}$ measurements, tissues were analysed whole. For $\delta^{13} \mathrm{C}$ analyses, lipids were extracted using a Soxhlet apparatus with chloroform as the solvent. A few aliquots were not lipid extracted; their values were corrected by adding a constant determined from $\delta^{13} \mathrm{C}$ measurements in the same prey samples, both delipidated and non-delipidated (Post et al. 2007). Lipids were removed from grebe muscles and yolk, but not from feathers or albumen due to their negligible lipid content (Kojadinovic et al. 2008). As the material available for smaller bodied taxa was limited, some samples consisted of pooled individuals collected from the same pond.

\section{Stable isotope analyses}

All feather types were measured for $\delta^{13} \mathrm{C}$; underwings were also measured for $\delta^{15} \mathrm{~N}$ and primaries for $\delta^{34} \mathrm{~S}$. Egg albumen, breast muscles and food sources were analysed for $\delta^{13} \mathrm{C}$, $\delta^{15} \mathrm{~N}$ and $\delta^{34} \mathrm{~S}$. Yolks were assayed only for $\delta^{13} \mathrm{C}$ and $\delta^{15} \mathrm{~N}$.

Dried and powdered tissue samples (approximately $1.0 \mathrm{mg}$ for $\mathrm{C}, 0.5 \mathrm{mg}$ for $\mathrm{N}$ and $0.4 \mathrm{~g}$ for $\mathrm{S}$ isotope analyses) were loaded into Pyrex glass ampoules [stable isotope analysis (SIA) for C and S] or tin capsules (SIA for N) for combustion. Stable $\mathrm{C}$ and $\mathrm{S}$ isotope measurements were made using a dual-inlet system triple-collector mass spectrometer at the Mass Spectrometry Laboratory of Maria CurieSkłodowska University (Lublin, Poland). Stable N isotope analyses were carried out by elemental analysis-isotope ratio mass spectrometry at Iso-Analytical (Cheshire, UK). Results are reported as per mil (\%o) relative to Vienna Pee Dee belemnite, atmospheric air, and Vienna Canyon Diablo

Table 1 Stable isotope values (mean \pm SD) of main prey sources and egg components in Red-necked Grebes

\begin{tabular}{llll}
\hline Samples & $\delta^{13} \mathrm{C}^{\mathrm{a}}(\% \circ)$ & $\delta^{15} \mathrm{~N}(\% \circ)$ & $\delta^{34} \mathrm{~S}(\% \circ)$ \\
\hline Amphibians $^{\mathrm{b}}$ & $-26.5 \pm 1.0(10)$ & $6.1 \pm 1.1(10)$ & $2.1 \pm 4.8(6)$ \\
Common Carp $^{\text {Leaf beetles }}{ }^{\mathrm{c}}$ & $-26.9 \pm 1.2(13)$ & $7.2 \pm 0.9(14)$ & $-4.9 \pm 3.8(5)$ \\
Coleoptera $^{\mathrm{d}}$ & $-24.2 \pm 1.2(9)$ & $3.3 \pm 0.5(8)$ & $5.2 \pm 2.3(4)$ \\
Grebe $_{\text {Egg albumen }}$ & $-27.4 \pm 1.5(12)$ & $6.7 \pm 1.0(11)$ & $1.9 \pm 3.7(10)$ \\
Grebe egg yolk & $-25.8 \pm 2.3(13)$ & $11.0 \pm 2.0(13)$ & $2.1 \pm 3.7(13)$ \\
\hline
\end{tabular}

Sample sizes are given in parentheses

${ }^{a}$ Analyses of $\delta^{13} \mathrm{C}$ were performed on lipid-extracted aliquots

${ }^{\mathrm{b}}$ Amphibians were adult anurans Pelobates fuscus, Hyla orientalis, Rana temporaria and Pelophylax sp.

${ }^{\mathrm{c}}$ Leaf beetles were Donaciinae, mainly Donacia cinerea

${ }^{\mathrm{d}}$ Coleoptera were Dytiscidae and Hydrophilidae imagines 
Troilite standards for $\mathrm{C}, \mathrm{N}$, and $\mathrm{S}$, respectively. For $\delta^{13} \mathrm{C}$ and $\delta^{34} \mathrm{~S}$ all samples were analysed in duplicate, with an average reproducibility of $0.2 \%$ and $0.5 \%$, respectively. For $\delta^{15} \mathrm{~N}, 20 \%$ of the analyses were performed in duplicate with a reproducibility of $0.2 \%$.

\section{Statistical analysis}

The samples were collected over several years, but due to small sample sizes per year (up to two samples of grebe tissues or prey), year effect was not considered in the analyses. Interannual differences in the location of wintering grounds and diet composition may have affected the results (cf. Hobson et al. 2011), but on the breeding grounds food sources were determined by pond culture regime and did not vary isotopically between years (Kloskowski and Trembaczowski 2015). Sample sizes also differed between analyses, mainly because of the varying amount of material for isotopic assays. Egg-laying dates were standardised to annual population means ( $n=12-38$ nests yearly); egg/carcass collection dates were not standardised (1 April=1). Since Red-necked Grebes are largely monomorphic (Kloskowski et al. 2006), the data for both sexes were pooled for the analyses aimed at determining the non-breeding environment and moult pattern (see also Results for lack of indication of non-breeding diet segregation between sexes on wintering grounds).

Isotopic values of feathers from different body parts were compared by Friedman ANOVA. Grubbs' test was applied to identify outliers (Grubbs 1969). Isotopic ratios in underwings were compared between sexes and between adults and fledglings using $t$-tests. All tests were two-tailed and conducted at the 5\% significance level. Unless otherwise stated, data are presented as mean \pm SD.

The proportional contributions of endogenous and exogenous sources of nutrients to eggs of early and later breeders (females arriving early in the season and laying eggs soon after arrival vs. females which arrived early but postponed breeding) were estimated using isotopic mixing models in a Bayesian framework. We used SIA in R, model SIAR version 4.1.3 with non-informative priors (Parnell et al. 2010), programmed in $\mathrm{R}$ version 3.5.1 ( $\mathrm{R}$ Core Team 2018). We applied three-isotope $\left(\delta^{13} \mathrm{C}, \delta^{15} \mathrm{~N}\right.$ and $\left.\delta^{34} \mathrm{~S}\right)$ models to determine the sources of proteins invested in albumen, and twoisotope $\left(\delta^{13} \mathrm{C}\right.$ and $\left.\delta^{15} \mathrm{~N}\right)$ models to infer the sources of nutrients allocated to yolk, with endogenous reserves considered one of the input sources. We used breast muscles from the three birds collected upon spring arrival as proxies for the endogenous reserves (Gauthier et al. 2003; Hobson et al. 2011), while the four freshwater prey groups outlined above (their mean isotopic values are shown in Table 1) represented exogenous nutrient sources. To compare nutrient allocation strategies, we considered eggs from six clutches started between 2 and 10 May (the first third of the early egg-laying period) and eggs from six clutches started between 17 and 31 May. The models incorporated elemental concentrations determined during isotopic assays and trophic enrichment factors (TEF; diet-tissue isotopic discrimination). Specific TEFs have not been measured for Red-necked Grebe, we used the $\delta^{13} \mathrm{C}$ and $\delta^{15} \mathrm{~N}$ TEF values of the carnivore model determined in falcons Falco spp. (Hobson (1995). For ${ }^{13} \mathrm{C}$ we assumed $0.9 \%$ enrichment in albumen and $0.0 \%$ depletion in lipid-free yolk, and for ${ }^{15} \mathrm{~N}, 3.1 \%$ in albumen and $3.5 \%$ enrichment in whole yolk. For ${ }^{34} \mathrm{~S}$ the TEF was set at 0.0\%o (Michener and Schell 1994; McCutchan et al. 2003; Florin et al. 2011). We used SD of $0.5 \%$ for all discrimination factors in the models. As a sensitivity analysis, we tested the effect of changing each discrimination factor between grebe eggs and nutrient sources by 1 SD. SIAR produced simulations of plausible values of dietary contributions with $25 \%, 75 \%$ and $95 \%$ credibility intervals.

To check for potential carry-over effects of the nonbreeding diet on subsequent reproduction, we regressed the first-egg date and mean egg volume $(n=15$ and 14 females, respectively) on $\delta^{13} \mathrm{C}$ and $\delta^{15} \mathrm{~N}$ values in underwing feathers. Owing to small sample sizes, we used simple (univariate) regressions, but to account for body size effect, we also checked models with body size index added as a covariable. We used bill size (bill length measured from the corner of the gape to the tip) instead of body mass as an individual size index because adults were captured during all stages of the breeding season, while their weight differed between incubation and the late chick stage irrespective of food availability in the ponds (Kloskowski et al. 2017). In the studied population, bill length was strongly correlated with the mass index scaled to body size (calculated following Peig and Green 2009, in Kloskowski et al. 2017), but its correlations with $\delta^{13} \mathrm{C}$ and $\delta^{15} \mathrm{~N}$ values were not significant (Pearson $r=0.08, p=0.699$ and $r=0.32, P=0.131$, respectively, $n=23)$.

\section{Results}

\section{Wintering ground signatures}

Grubbs' tests on $\delta^{13} \mathrm{C}$ in feathers collected from different body regions and on $\delta^{34} \mathrm{~S}$ in primaries indicated the presence of outliers (all $p<0.05$ ). All outliers were due to comparatively strong isotopic depletion in the feathers of one male ringed as a breeder in 2003 and found dead on its nest on the same pond in late May 2004 (Fig. 1). Otherwise, adult feathers displayed highly enriched $\delta^{13} \mathrm{C}$ values, nearly all of them $>-20 \%$ (Fig. 1), while $\delta^{34}$ S values in primaries of all birds were $>10 \%$ (mean $14.3 \pm \mathrm{SD}$ $2.6 \%$, range $10.2 \%$ o to $18.2 \%$; outlier individual $5.2 \%$ ) . 


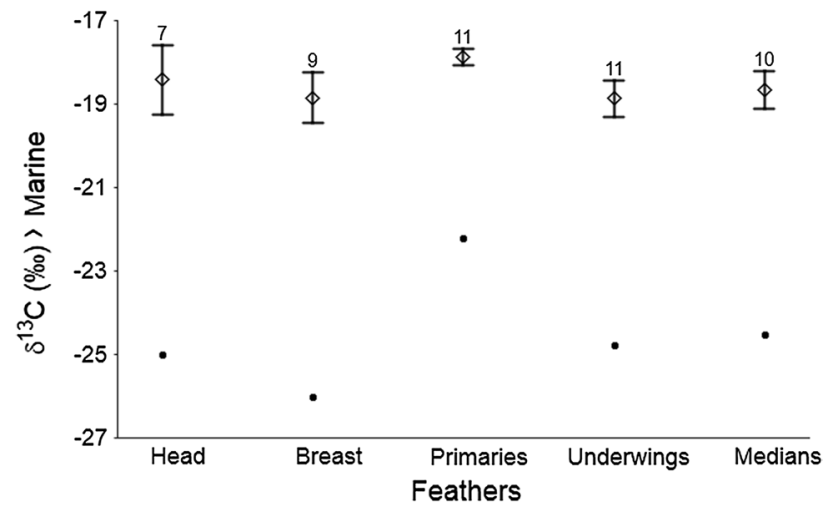

Fig. 1 Stable carbon isotope values $\left(\delta^{13} \mathrm{C}\right)$ (means \pm SEs) of Rednecked Grebe feathers from different regions of the body. Females and males were considered together. Black dots indicate outliers, all originating from a single bird (male SA02594)

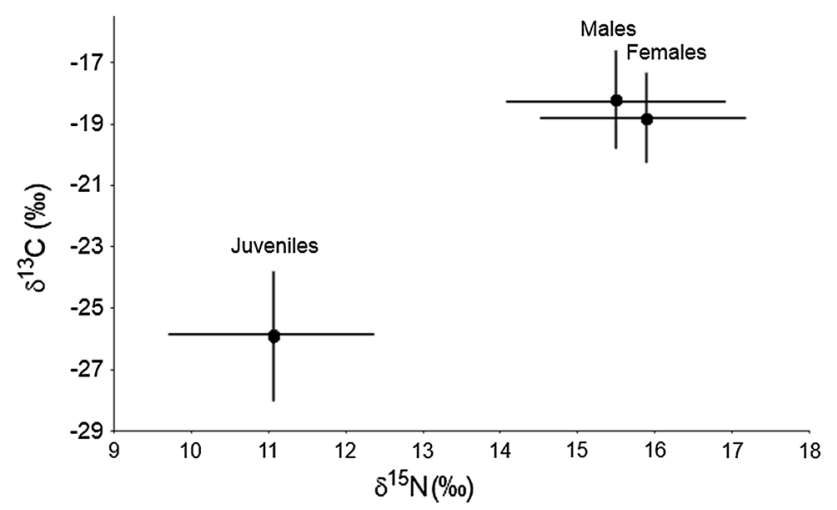

Fig. 2 Mean $\left( \pm 1\right.$ SD) $\delta^{13} \mathrm{C}$ and nitrogen isotope signatures $\left(\delta^{15} \mathrm{~N}\right)$ in underwing coverts of adult males $(n=7)$, adult females $(n=20)$, and juveniles (birds approaching fledging, $n=25$ )

By contrast, underwing coverts of the outlier male were more enriched in ${ }^{15} \mathrm{~N}(20.3 \%)$ than underwings of the other sampled grebes (mean $15.6 \pm 0.8 \%$; cf. Fig. 2).

After exclusion of the outlier male, Friedman ANOVA, performed on birds for which a complete set of feathers could be collected $(n=7)$, indicated no significant differences in $\delta^{13} \mathrm{C}$ values between feather types $\left(\chi^{2}{ }_{4}=2.63\right.$, $p=0.622)$. In a larger sample including birds sampled alive, $\delta^{13} \mathrm{C}$ and $\delta^{15} \mathrm{~N}$ in underwing coverts were statistically indistinguishable between males and females (both $t_{25} \leq 0.51, p>0.5$; Fig. 2). Adult underwing coverts were significantly more enriched in ${ }^{13} \mathrm{C}$ and ${ }^{15} \mathrm{~N}$ than those of fledglings (both $t_{50} \geq 11.22, p<0.001$; Fig. 2). Freshwater prey was always depleted in ${ }^{13} \mathrm{C}$ below the level of $-24 \%$, with $\delta^{15} \mathrm{~N}$ and $\delta^{34} \mathrm{~S}$ values below $10 \%$ (Table 1).

\section{Nutrient transfer and allocation}

The breast muscle values of females collected upon arrival, $\delta^{13} \mathrm{C}-17.3 \%$ and $-16.5 \%$, and $\delta^{15} \mathrm{~N} 14.2 \%$ and $14.9 \%$, were within the value ranges of the analysed adult feathers (Figs. 1, 2). The $\delta^{34} \mathrm{~S}$ values, $18.3 \%$ and $19.7 \%$, exceeded the $\delta^{34} \mathrm{~S}$ range in adult primaries. The muscles were considerably isotopically enriched compared to freshwater prey, which displayed high isotopic variability (Table 1). The $\delta^{15} \mathrm{~N}$ pattern reflected a trophic hierarchy with fish at the top and leaf beetles at the bottom of the pond trophic chains (Table 1). $\delta^{34} \mathrm{~S}$ values were the most variable among the prey groups (range -11.4 to $8.7 \%$ ), also with strong variation within prey groups. This was particularly prominent in amphibians, for which $\delta^{34} \mathrm{~S}$ values fell in a range from $-6.9 \%$ to $7.0 \%$. Nonetheless, when compared with mean values of local prey items exhibiting the highest isotope ratios (for $\delta^{13} \mathrm{C}$ and $\delta^{34} \mathrm{~S}$ of leaf beetles, and for $\delta^{15} \mathrm{~N}$ of fish; Table 1), the breast muscles of the earliest arrived birds were more enriched, by about $10 \%, 13 \%$ and $7 \%$, respectively, for $\delta^{13} \mathrm{C}, \delta^{34} \mathrm{~S}$ and $\delta^{15} \mathrm{~N}$. The muscle isotopic values declined with the date of collection $\left(\delta^{13} \mathrm{C}, r^{2}=0.91\right.$, $P<0.001 ; \delta^{15} \mathrm{~N}, r^{2}=0.63, P=0.011, \delta^{34} \mathrm{~S}, r^{2}=0.55$, $p=0.022 ; n=9$, Fig. 3a-c). In mid-May muscle tissues displayed isotopic signatures aligned with those of freshwater prey (Fig. 3a-c).

The levels of $\delta^{15} \mathrm{~N}$ and $\delta^{34} \mathrm{~S}$ in egg albumen tended to decline as the season progressed, though for ${ }^{34} \mathrm{~S}$ the association only approached significance $\left(r^{2}=0.34, p=0.035\right.$ and $\mathrm{r}^{2}=0.24, p=0.089$, respectively). In contrast, the increase in $\delta^{13} \mathrm{C}$ was only marginally significant, $r^{2}=0.30$, $p=0.053$ (Fig. 3a-c). For yolk, we found no trend in $\delta^{13} \mathrm{C}$ values, while $\delta^{15} \mathrm{~N}$ levels marginally decreased with time, $r^{2}=0.07, p=0.375$ and $r^{2}=0.24, p=0.090$, respectively (Fig. 3a, b). Albumen and yolk $\delta^{13} \mathrm{C}$ and $\delta^{15} \mathrm{~N}$ values from the same egg were correlated (Spearman $r>0.67, n=13$, both $p<0.012$ ), indicating similar origins of $\mathrm{C}$ and $\mathrm{N}$ in both egg components.

The mixing models revealed that proportions of possible endogenous nutrients differed between eggs laid early and later in the season. Early breeders mobilised a significant proportion of endogenous nutrients to form eggs (95\% credible interval $=25-26 \%$ and $17-18 \%$ for albumen and lipidfree yolk, respectively; Fig. 4). Later breeders produced eggs primarily, if not entirely, from exogenous sources [95\% credible interval for endogenous contribution $=3.3-3.6 \%$ (albumen) and 0.6-0.7\% (yolk); Fig. 4]. In response to reducing or increasing the TEFs for all elements by $1 \mathrm{SD}$, Bayesian estimates of endogenous contributions to albumen and yolk of early laid eggs increased or decreased, respectively, 

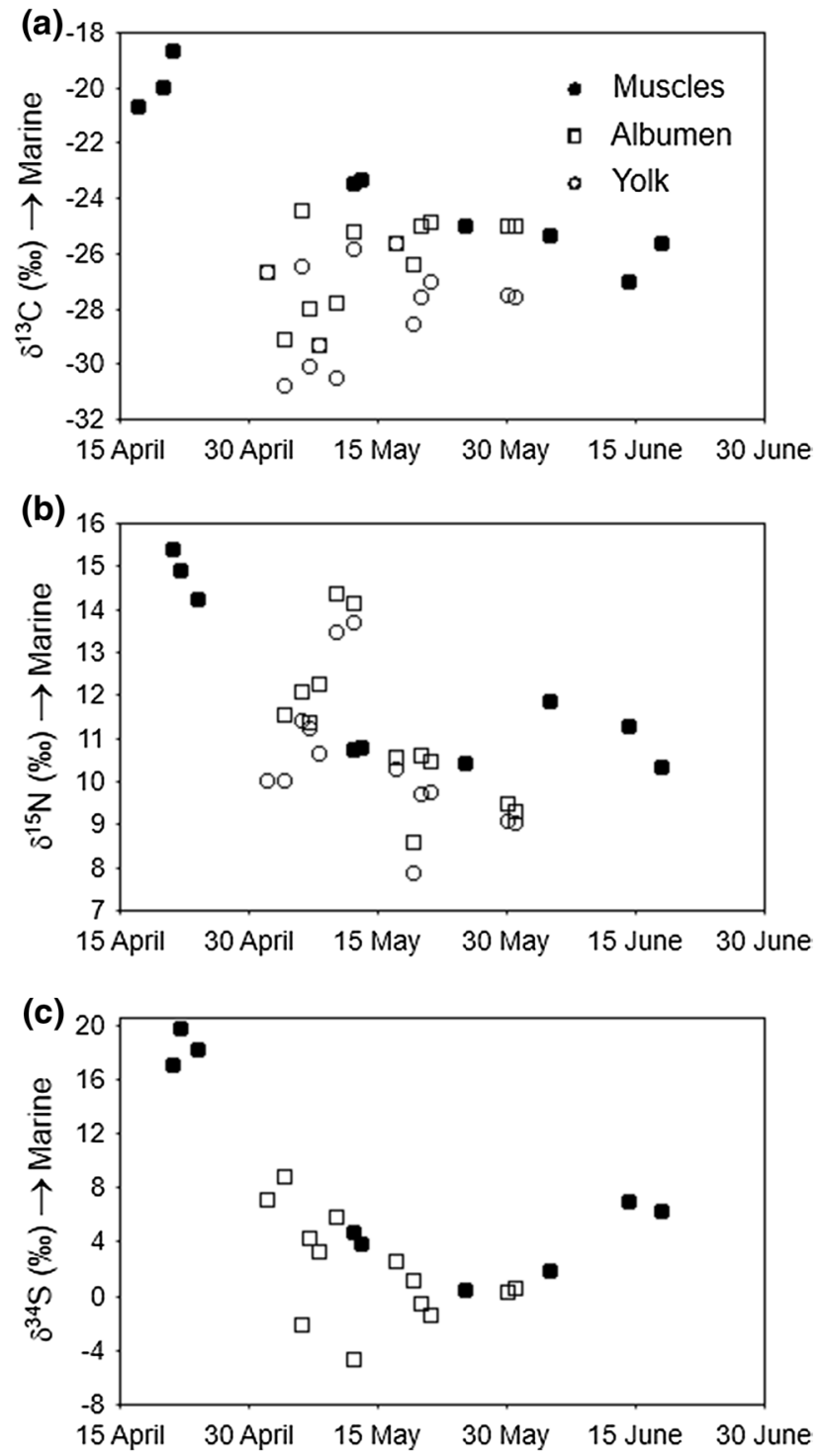

Fig. 3 a $\delta^{13} \mathrm{C}, \mathbf{b} \delta^{15} \mathrm{~N}$ and $\mathbf{c} \delta^{34} S$ in Red-necked Grebe breast muscles and egg tissues collected at different stages of the breeding season. $\delta^{13} \mathrm{C}$ analyses were performed on lipid-free samples. $\delta^{34} \mathrm{~S}$ analyses were not run on yolk. Note that samples were collected in different years

by less than $3 \%$, with the exception of yolk, for which the estimate fell by $5 \%$ in response to increased TEF. Also, in no model for eggs laid later did the estimated endogenous contribution to yolk exceed $1 \%$.

\section{Carry-over effects on breeding performance}

First egg-laying dates were related to $\delta^{15} \mathrm{~N}$ in female underwing feathers (Fig. 5). Also, mean egg volume increased with increasing feather $\delta^{15} \mathrm{~N}$ values (Fig. 5). Mean egg volume was unrelated to the laying date

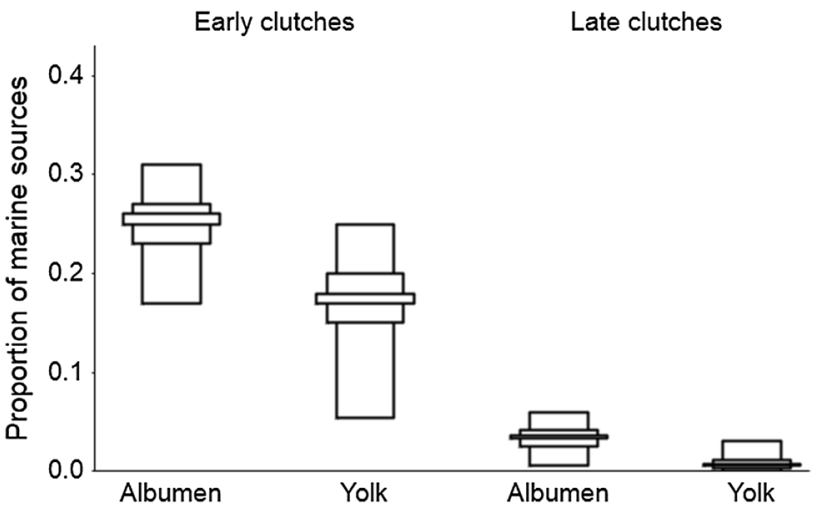

Fig. 4 Contributions of endogenous reserves to albumen and yolk of early and later breeding Red-necked Grebes, provided by the Bayesian mixing model with $95 \%, 75 \%$ and $25 \%$ credibility intervals

$\left(r^{2}=0.001 ; p=0.917\right)$. When bill size was added as a covariate to the models, the effect of $\delta^{15} \mathrm{~N}$ remained significant $\left(\mathrm{F}_{1,11}=9.46 ; p=0.011\right)$ for timing of laying but not for egg volume $\left(\mathrm{F}_{1,10}=2.48 ; p=0.146\right)$. The importance of bill size in the models was minor $\left(\mathrm{F}_{1,11}=0.17\right.$; $p=0.687$ and $\left.\mathrm{F}_{1,10}=1.34 ; p=0.273\right) . \delta^{13} \mathrm{C}$ in underwing feathers was related neither to first egg date nor to egg size (both $p>0.7$ ).

\section{Discussion}

\section{Moulting habitats}

$\delta^{13} \mathrm{C}$ and $\delta^{15} \mathrm{~N}$ values in the feathers of adult grebes were substantially elevated compared to those of juvenile birds and food sources on breeding grounds. The isotopic values of juvenile feathers fit well with the isotopic ranges apparent in freshwater prey after accounting for enrichment between diet and feather tissues [approximately $2.3-3.8 \%$ for $\delta^{13} \mathrm{C}$ and $3.7-5.3 \%$ or $\delta^{15} \mathrm{~N}$ in fish-eating birds (Mizutani et al. 1992; Bearhop et al. 1999)]. With the exception of the outlier male, the adult feathers had $\delta^{13} \mathrm{C}$ and $\delta^{34} \mathrm{~S}$ values higher than or close to the cutoffs recommended as indicative of a marine diet (Fry and Sherr 1989; Lott et al. 2003). The data do not allow for determination of the exact geographical location of the moult or definite exclusion of various marineassociated waters as moulting habitats. The feather isotopic signals matched $\delta^{13} \mathrm{C}, \delta^{15} \mathrm{~N}$ and $\delta^{34} \mathrm{~S}$ values characteristic of eastern Baltic benthic and benthopelagic fish, shown to be the main components of the winter diet of the Great Crested Grebe Podiceps cristatus (Morkūnè et al. 2016), a close relative of the Red-necked Grebe. However, these data merely demonstrate that the Red-necked Grebe's non-breeding diet fits Baltic food webs, otherwise the diet can be highly variable (Byrkjedal et al. 1997; reviewed in Vlug 2018), and 

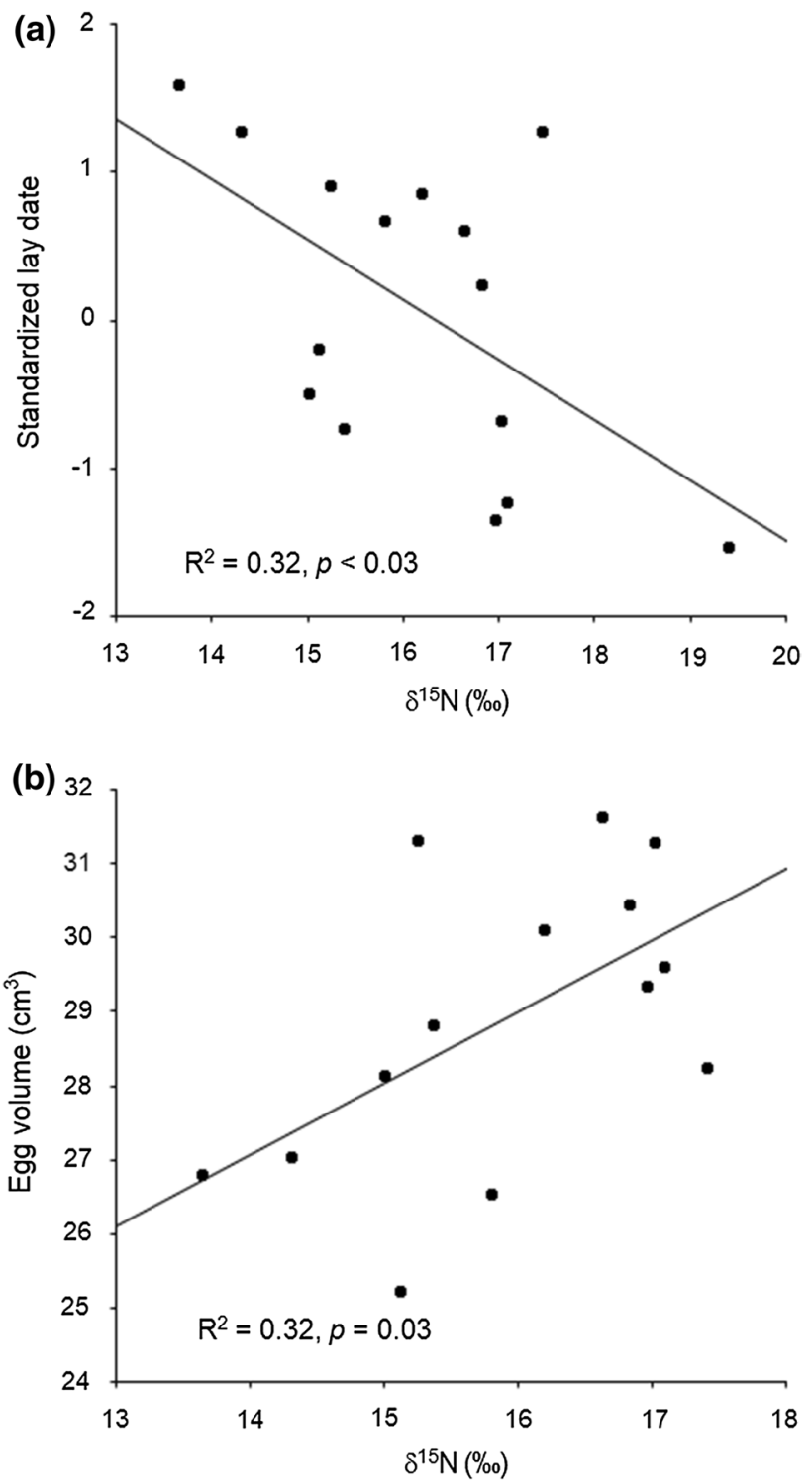

Fig. 5 Relationships between $\delta^{15} \mathrm{~N}$ of underwing coverts of female Red-necked Grebes and $\mathbf{a}$ first-egg dates and $\mathbf{b}$ egg volumes

food sources may differ isotopically between the western and eastern Baltic Sea (Deutsch and Berth 2006).

The $\delta^{13} \mathrm{C}$ and $\delta^{34} \mathrm{~S}$ values of the outlier were indicative of feather growth occurring in a freshwater ecosystem, although the high $\delta^{15} \mathrm{~N}$ values pointed to a marine-associated habitat (Hobson et al. 1994), or at least a system supporting a long trophic chain (Vander Zanden and Rasmussen 1999). The anomalous values cannot be explained by the post-juvenile moult pattern, as the outlier male had been ringed as a breeder a year before. Feathers from different body parts of the grebes collected dead were obviously formed from nutrients garnered from the same isotopic landscape. Although adult Red-necked Grebes are likely to replace flight feathers only once during the post-breeding moult, while most of the other feathers are changed again during the pre-breeding moult (Vlug 2018; see also Piersma 1988), the isotopic similarity of different feathers indicates that the entire moult was completed in the same habitat.

\section{Nutrient transfer and allocation to eggs}

Isotopic signatures of the breast muscles of birds collected during the initial settling period revealed that Red-necked Grebes arrived at freshwater breeding areas with body stores distinctly more enriched in ${ }^{13} \mathrm{C},{ }^{15} \mathrm{~N}$ and ${ }^{34} \mathrm{~S}$ than would be expected had nutrients been obtained solely from the inland food webs. It remains uncertain whether the muscles of newly arrived birds accurately represent capital endpoints, because birds may utilise nutrients originating from a marine food base during migration and replenish them during stopovers at freshwater sites (Klaassen et al. 2006). However, the muscle isotopic values were at similar levels or higher than those of feathers, indicating that Red-necked Grebes preserved the stores from marine sites. Owing to their strong correlation with trophic status and varying fractionation factors (Minagawa and Wada 1984; Hart and Lovvorn 2002), ${ }^{15} \mathrm{~N}$ signatures of consumers are less informative about the biome from which nutrients were derived; however, values in the order of $15 \%$ observed both in adult feathers and in muscles of birds collected upon arrival were typical for primarily piscivorous marine species (Hobson et al. 1994). $\delta^{15} \mathrm{~N}$ signals of juvenile feathers never reached $15 \%$.

The outcomes of the mixing models indicate that grebes used mainly exogenous nutrients for egg production; however, the strategy of nutrient allocation varied with the time of the season. A significant, though not large, portion of albumen and yolk nutrients in eggs of early breeding grebes was derived from endogenous reserves, while marine nutrients were used to a much lesser degree, or not at all, in later nesting females. Although we would expect grebes to synthesise proteins for egg formation directly from their local diet (Hobson et al. 1997; DeVink et al. 2011; Sénéchal et al. 2011), we found some evidence for routing of endogenous proteins to albumen by early breeding birds. The Bayesian estimates of endogenous nutrient deposition to lipid-free yolk tended to be lower than those for albumen (see also Hahn et al. 2011); however, they were based on only twoisotope $\left(\delta^{13} \mathrm{C}\right.$ and $\left.\delta^{15} \mathrm{~N}\right)$ models, which may have lowered their power to distinguish between marine and terrestrial/ freshwater food sources (Moreno et al. 2010). Inferences about nutrient transfer from muscle isotopic compositions of spring-arriving birds should be made with caution because nutritional stress or prolonged metabolic expenditure associated with migration may induce tissue $\delta^{13} \mathrm{C}$ and $\delta^{15} \mathrm{~N}$ enrichment (Doucett et al. 1999; Cherel et al. 2005). However, 
breast muscle values of newly arrived birds, used here as capital endpoints, were reasonably consistent with isotopic feather values (cf. DeVink et al. 2011). Also, poor physiological state does not explain the elevated $\delta^{34} \mathrm{~S}$ values in the muscles of early arrivals. Since the TEFs between sources and egg components were inferred from the literature for other species, the mixing models provide rough approximations rather than exact estimates of source contributions to the isotopic composition of Red-necked Grebe eggs (Bond and Diamond 2011). The processes of isotopic discrimination can vary not only among species but also with diet quality, among tissues, or among physiological pathways (e.g. Vanderklift and Ponsard 2003; Florin et al. 2011). Our models are consistent with the negative seasonal trends in albumen $\delta^{15} \mathrm{~N}$ and $\delta^{34} \mathrm{~S}$ values (Morrison and Hobson 2004); however, the weak opposite tendency in albumen $\delta^{13} \mathrm{C}$ contradicts the pattern of increasing exogenous contribution as the breeding season progresses. We acknowledge that the trends may have been, at least in part, driven by within-season changes in the local diet composition (cf. Langin et al. 2006). $\delta^{15} \mathrm{~N}$ values are especially sensitive to small spatial scale processes and shifts in trophic status (Hart and Lovvorn 2002; McCutchan et al. 2003). Still, we would rather expect a seasonal increase in $\delta^{15} \mathrm{~N}$ for eggs had they been synthesised entirely from locally derived nutrients. Pond food webs become more complex with the progress of the season, which may result in lengthened food chains and thus increased $\delta^{15} \mathrm{~N}$ levels in tissues of top predators (McParland et al. 2010). The isotopic patterns reflecting nutrient acquisition by grebes might be additionally complicated because a varying proportion of their prey originated from terrestrial food webs, potentially differing in $\delta^{13} \mathrm{C}$ and $\delta^{34} \mathrm{~S}$ signals from freshwater biomes (Kloskowski and Trembaczowski 2015; see also Croisetière et al. 2009). We observed particularly large variation in amphibian $\delta^{34} \mathrm{~S}$ signatures, presumably because most of the sampled species are terrestrial and enter small waterbodies only for reproduction, while others (water frogs Pelophylax sp.) are strongly associated with aquatic habitats during their active season. Moreover, eggs and samples of grebe prey were collected from ponds with different water sources and thus presumably varied by location in baseline isotopic values (Vander Zanden and Rasmussen 1999; Hart and Lovvorn 2002). However, despite marked isotopic variation among freshwater prey, the isotopic segregation between pond food webs and the presumed marine-grown grebe tissues was sufficient to permit inferences about the origins of nutrients in eggs.

Although we conclude that Red-necked Grebes are generally income breeders, this study provides, to our knowledge, the first indication of endogenous nutrient mobilisation for egg production in Podicipediformes. Earlier research on the trophic ecology of Red-necked Grebes (the North American subspecies Podiceps grisegena holboellii) on boreal lakes in
Canada suggested that females incorporated locally derived nutrients into eggs (Paszkowski et al. 2004). Our previous study on exploitation of local resources by grebes, using yolks from eggs collected mainly in mid-season, led to basically the same conclusion (Kloskowski and Trembaczowski 2015). Here we used eggs laid early in the season. Notably, in the study by Paszkowski et al. (2004), $\delta^{13} \mathrm{C}$ and $\delta^{15} \mathrm{~N}$ values in the pectoral muscles of adult birds were clearly lower than in the primary feathers and did not decline as the season progressed (see also Newbrey et al. 2012). We have found an opposite seasonal pattern (also for $\delta^{34} \mathrm{~S}$ ). Generally, mobilisation of stored reserves would be more expected in species where only the female incubates and thus depletion of nutrient reserves may affect incubation success (Gloutney and Clark 1991; Mallory and Weatherhead 1993). In birds such as grebes, in which both sexes share parental duties and clutches are initiated with some delay after the return to the breeding grounds, females can devote a considerable proportion of their time to foraging immediately before laying (Kloskowski et al. 2012). When the pre-laying period is relatively long, the question arises regarding pathways of storing endogenous macronutrients over longer times and later use of them on demand (Burley and Vadehra 1989). On the other hand, the Red-necked Grebe remains a likely candidate for adoption of a mixed capital/income strategy, as it breeds mainly in cold climates at northern latitudes. The European subspecies is of smaller size, including a shorter bill, and apparently less piscivorous than its North American counterpart (Fjeldså 1982). It commonly nests on non-permanent, shallow, fishless waterbodies (Vlug 2018), where food supplies are low shortly after ice-out (in some years wetlands are still partially frozen during arrival) or after spring flooding (cf. Kloskowski 2012). Early breeding females may find it difficult to acquire sufficient nutrients and energy during the immediate post-arrival period, and even a small endogenous input of critical nutrients could facilitate egg production. The pattern observed in this study is also consistent with the lifehistory-based hypothesis that capital breeding should be favoured early in the season when offspring reproductive value is highest (Jaatinen et al. 2016). Grebes from the studied mid-continent population are shortdistance migrants and may invest more of their endogenous reserves in egg production due to the lower costs of nutrient transport and lower probability of reserve depletion before arrival (Klaassen et al. 2006; Hobson et al. 2011). Endogenous reserves can confer fitness advantages even if they do not provide the bulk of nutrients for egg formation, as they help females to cope with early season food shortages, inclement weather, or energetic costs of territory acquisition, whereas nutrients from local foods are directed into eggs (Hobson et al. 2004; Langin et al. 2006; Schmutz et al. 2006). However, it is not clear whether grebes are capable 
of building up substantial body stores, or when rapid follicle growth is initiated (Oppel et al. 2010).

\section{Carry-over effects}

Our results support the prediction that the timing of reproduction in Red-necked Grebes is influenced by the quality of food consumed during the non-breeding season. Data on the body condition of arriving grebes were not available, but females whose feathers had elevated $\delta^{15} \mathrm{~N}$ levels nested early in the season. High ${ }^{15} \mathrm{~N}$ enrichment indicates a greater proportion of prey from higher trophic levels in the diet, which is typically of better dietary quality due to its higher energy content (Becker et al. 2007). Red-necked Grebes consume a mixed diet of fish and macroinvertebrates wherein fish exploitation is limited by size; feeding on higher trophic level prey typically means a larger proportion of fish in the diet (Fjeldså 1982; Paszkowski et al. 2004). Marine fish are typically higher level consumers and provide greater energetic and nutritional return than invertebrates (but see Sorensen et al. 2009), and thus are a preferred resource, although they may require better foraging skills (Byrkjedal et al. 1997). Isotope ratios can be affected by a variety of abiotic and biotic factors, and we cannot rule out that the differences observed in $\delta^{15} \mathrm{~N}$ simply resulted from moulting of feathers in divergent geographical locations (cf. Sorensen et al. 2009). However, feathers of all sampled females had fairly uniform $\delta^{13} \mathrm{C}$ signals, indicating that they were moulted in the same broad area. Also, besides individual variation, our data are likely to reflect between-year differences related to climatic variability (Becker et al. 2007).

Apart from the advantages of early breeding for offspring value (reviewed in Williams et al. 2017), Red-necked Grebe females that start laying early in the season have better options for initiating a replacement clutch in case of nest/ brood failure in the face of a short breeding season; only the earliest breeding pairs are capable of double-brooding (Kloskowski 2001). In natural shallow habitats, which are prone to drying out during warm periods, early breeding increases the probability of the young fledging before water levels drop. Carry-over effects on reproductive parameters are difficult to separate from intrinsic (parental) quality (Blomqvist et al. 1997; Daunt et al. 2006). Larger-sized individuals usually lay larger eggs (Alisauskas and Ankney 1992; but see Boon and Ankney 1999) and forage more efficiently on large-bodied, trophically high prey (Newbrey et al. 2012). Thus they obtain a higher quality diet and are then able to initiate reproduction earlier than smaller individuals (Klaassen et al. 2006). In our study, body size indeed affected the relationship of feather $\delta^{15} \mathrm{~N}$ to egg size, but not to laying date.

Carry-over effects from non-breeding grounds present an exciting new challenge for researchers as they help us to understand the year-round ecology of migratory animals. Provided that there is a detectable difference between nonbreeding and breeding isotopic regions, the stable isotope approach has the potential to be useful in evaluating the cross-seasonal processes of matter and energy allocation to reproduction. Our findings indicate that Red-necked Grebes arrive on breeding grounds with marine-derived nutrient stores but mainly use locally acquired nutrients for egg formation, and that the quality of food at the wintering grounds has consequences for subsequent breeding performance. However, we observed differences in the relative proportions of endogenous and local nutrients among females with respect to the onset of breeding (Hobson et al. 2004; Morrison and Hobson 2004; Hahn et al. 2011). Our study illustrates the importance of research on factors governing variation in the length of the pre-laying period, as the arrival-clutch initiation interval may be as important for reproductive investment as the timing of breeding itself (Bêty et al. 2003; Klaassen et al. 2006). Another point that warrants further investigation is plasticity in nutrient allocation (Oppel et al. 2010; DeVink et al. 2011; Jaatinen et al. 2016) by the earliest breeding birds, typically individuals in good pre-breeding condition (Boon and Ankney 1999; Bêty et al. 2003). In Red-necked Grebes, the first females to initiate egg-laying fed on the highest quality food during the non-breeding season, and some residual macronutrients garnered in marine environments were deposited in their eggs.

Acknowledgements We thank J. Krogulec, M. Polak, M. Stróżek, P. Szewczyk and many volunteers for assistance in the field. J. Bellebaum and an anonymous reviewer provided valuable comments on the manuscript. This study was supported by grants from the State Committee for Scientific Research (KBN 6PO4F06620 and 3PO4F03623) and from the Polish Ministry of Science and Higher Education (MNiSW 2P04G05030). Permission to collect samples for isotope analyses was granted by the Local Ethical Commission (Lublin) and the Ministry of the Environment. All the reported work complied with the applicable Polish law.

Open Access This article is distributed under the terms of the Creative Commons Attribution 4.0 International License (http://creativeco mmons.org/licenses/by/4.0/), which permits unrestricted use, distribution, and reproduction in any medium, provided you give appropriate credit to the original author(s) and the source, provide a link to the Creative Commons license, and indicate if changes were made.

\section{References}

Alisauskas RT, Ankney CD (1992) The cost of egg laying and its relationship to nutrient reserves in waterfowl. In: Batt BDJ (ed) Ecology and management of breeding waterfowl. University of Minnesota Press, Minneapolis, MN, pp 30-61

Baker K (1993) Identification guide to European non-passerines. British Trust for Ornithology, Thetford 
Bearhop S, Thompson DR, Waldron S, Russell IC, Alexander G, Furness RW (1999) Stable isotopes indicate the extent of freshwater feeding by Cormorants Phalacrocorax carbo shot at inland fisheries in England. J Appl Ecol 36:75-84

Becker BH, Peery MZ, Beissinger SR (2007) Ocean climate and prey availability affect the trophic level and reproductive success of the Marbled Murrelet, an endangered seabird. Mar Ecol Prog Ser 329:267-279

Bellebaum J, Szostek KL, Kloskowski J (2018) Population dynamics and survival of the Red-necked Grebe Podiceps grisegena: results from a long-term study in eastern Poland. J Ornithol 159:631-641

Bêty J, Gauthier G, Giroux JF (2003) Body condition, migration, and timing of reproduction in Snow Geese: a test of the conditiondependent model of optimal clutch size. Am Nat 162:110-121

Blomqvist D, Johansson OC, Götmark F (1997) Parental quality and egg size affect chick survival in a precocial bird, the Lapwing Vanellus vanellus. Oecologia 110:18-24

Bond AL, Diamond AW (2011) Recent Bayesian stable-isotope mixing models are highly sensitive to variation in discrimination factors. Ecol Appl 21:1017-1023

Boon LA, Ankney CD (1999) Body size, nest initiation date, and egg production in Ruddy Ducks. Auk 116:228-231

Burley RW, Vadehra DV (1989) The avian egg: chemistry and biology. Wiley, New York

Byrkjedal I, Eldøy S, Grundetjern S, Løyning MK (1997) Feeding associations between Red-necked Grebes Podiceps griseigena and Velvet Scoters Melanitta fusca in winter. Ibis 139:45-50

Cherel Y, Hobson KA, Bailleul F, Groscolas R (2005) Nutrition, physiology, and stable isotopes: new information from fasting and molting penguins. Ecology 86:2881-2888

Chisholm BS, Nelson DE, Schwarcz HP (1982) Stable-carbon isotope ratios as a measure of marine versus terrestrial protein in ancient diets. Science 216:1131-1132

Core Team R (2018) R: a language and environment for statistical computing. R Foundation for Statistical Computing, Vienna, Austria https://www.r-project.org/

Croisetière L, Hare L, Tessier A, Cabana G (2009) Sulphur stable isotopes can distinguish trophic dependence on sediments and plankton in boreal lakes. Freshwater Biol 54:1006-1015

Daunt F, Afanasyev V, Silk JRD, Wanless S (2006) Extrinsic and intrinsic determinants of winter foraging and breeding phenology in a temperate seabird. Behav Ecol Sociobiol 59:381-388

Deutsch B, Berth U (2006) Differentiation of western and eastern Baltic Sea Cod stocks (Gadus morhua) by means of stable isotope ratios in muscles and otoliths. J Appl Ichthyol 22:538-539

DeVink JM, Slattery SM, Clark RG, Alisauskas RT, Hobson KA (2011) Combining stable isotope and body composition analysis to assess nutrient allocation strategies in White-winged Scoters. Auk 128:166-174

Doucett RR, Booth RK, Power G, McKinley RS (1999) Effects of the spawning migration on the nutritional status of anadromous Atlantic Salmon (Salmo salar): insights from stable-isotope analysis. Can J Fish Aquat Sci 56:2172-2180

Drent RH, Daan S (1980) The prudent parent: energetic adjustments in avian breeding. Ardea 68:225-252

Fjeldså J (1982) The adaptive significance of local variations in the bill and jaw anatomy of North European Red-necked Grebes Podiceps grisegena. Ornis Fenn 59:84-98

Florin ST, Felicetti LA, Robbins CT (2011) The biological basis for understanding and predicting dietary-induced variation in nitrogen and sulphur isotope ratio discrimination. Funct Ecol 25:519-526

Fry B, Sherr EB (1989) $\delta 13 C$ measurements as indicators of carbon flow in marine and freshwater ecosystems. In: Rundel PW, Ehleringer JR, Nagy KA (eds) Stable isotopes in ecological research. Springer, New York, pp 196-229
Gauthier GJ, Bêty J, Hobson KA (2003) Are greater Snow Geese capital breeders? New evidence from a stable isotope model. Ecology $84: 3250-3264$

Gloutney ML, Clark RG (1991) The significance of body mass to female dabbling ducks during late incubation. Condor 93:811-816

Grubbs FE (1969) Procedures for detecting outlying observations in samples. Technometrics 11:1-21

Hahn S, Loonen MJ, Klaassen M (2011) The reliance on distant resources for egg formation in high Arctic breeding Barnacle Geese Branta leucopsis. J Avian Biol 42:159-168

Hart EA, Lovvorn JR (2002) Interpreting stable isotopes from macroinvertebrate foodwebs in saline wetlands. Limnol Oceanogr 47:580-584

Hobson KA, Piatt JF, Pitocchelli J (1994) Using stable isotopes to determine seabird trophic relationships. J Anim Ecol 63:786-798

Hobson KA (1995) Reconstructing avian diets using stable-carbon and nitrogen isotope analysis of egg components: patterns of isotopic fractionation and turnover. Condor 97:752-762

Hobson KA, Hughes KD, Ewins PJ (1997) Using stable-isotope analysis to identify endogenous and exogenous sources of nutrients in eggs of migratory birds: Applications to Great Lakes contaminants research. Auk 114:467-478

Hobson KA, Atwell L, Wassenaar LI, Yerkes T (2004) Estimating endogenous nutrient allocations to reproduction in Redhead Ducks: a dual isotope approach using $\delta \mathrm{D}$ and $\delta^{13} \mathrm{C}$ measurements of female and egg tissues. Funct Ecol 18:737-745

Hobson KA, Sharp CM, Jeffries RL, Rockwell RF, Abraham KF (2011) Nutrient allocation strategies to eggs by Lesser Snow Geese at a sub Arctic colony. Auk 128:156-165

Hoyt DF (1979) Practical methods of estimating volume and fresh weight of bird eggs. Auk 96:73-77

Jaatinen K, Öst M, Hobson KA (2016) State-dependent capital and income breeding: a novel approach to evaluating individual strategies with stable isotopes. Front Zool 13:24

Janke AK, Anteau MJ, Mark1 N, Stafford JD (2015) Is income breeding an appropriate construct for waterfowl? J Ornithol 156:755-762

Klaassen M, Abraham KF, Jefferies RL, Vrtiska M (2006) Factors affecting the site of investment, and the reliance on savings for arctic breeders: the capital-income dichotomy revisited. Ardea 94:371-384

Kloskowski J (2001) Double-brooding in Red-necked Grebes. Waterbirds 24:121-124

Kloskowski J, Grela P, Krogulec J, Gąska M, Tchórzewski M (2006) Sexing Red-necked Grebes Podiceps grisegena by molecular techniques and morphology. Acta Ornithol 41:176-180

Kloskowski J, Grela P, Gąska M (2012) The role of male nest building in post-mating sexual selection in the monogamous Red-necked Grebe. Behaviour 149:81-98

Kloskowski J (2012) Fish stocking creates an ecological trap for an avian predator via effects on prey availability. Oikos 121:1567-1576

Kloskowski J, Trembaczowski A (2015) Fish reduce habitat coupling by a waterbird: evidence from combined stable isotope and conventional dietary approaches. Aquat Ecol 49:21-31

Kloskowski J, Kaczanowska E, Krogulec J, Grela P (2017) Hematological indicators of habitat quality: Erythrocyte parameters reflect greater parental effort of Red-necked Grebes under ecological trap conditions. Condor 119:239-250

Kojadinovic J, Ricjard P, Le Corre M, Cosson RP, Bustamante P (2008) Effects of lipid extraction on $\delta^{13} \mathrm{C}$ and $\delta^{15} \mathrm{~N}$ values in seabird muscle, liver and feathers. Waterbirds 31:169-178

Langin KM, Norris DR, Kyser TK, Marra PP, Ratcliffe LM (2006) Capital versus income breeding in a migratory passerine bird: evidence from stable-carbon isotopes. Can J Zool 84:947-953 
Lehikoinen A, Kilpi M, Öst M (2006) Winter climate affects subsequent breeding success of Common Eiders. Glob Change Biol 12:1355-1365

Lott CA, Meehan TD, Heath JA (2003) Estimating the latitudinal origins of migratory birds using hydrogen and sulfur stable isotopes in feathers: influence of marine prey base. Oecologia 134:505-510

Mallory ML, Weatherhead PJ (1993) Incubation rhythms and mass loss of Common Goldeneyes. Condor 95:849-859

Marra PP, Hobson KA, Holmes RT (1998) Linking winter and summer events in a migratory bird using stable carbon isotopes. Science 282:1884-1886

McConnaughey T, McRoy CP (1979) Food-web structure and the fractionation of carbon isotopes in the Bering Sea. Mar Biol $53: 257-262$

McCutchan JH, Lewis WM, Kendall C, McGrath CC (2003) Variation in trophic shift for stable isotope ratios of carbon, nitrogen, and sulfur. Oikos 102:378-390

McParland CE, Paszkowski CA, Newbrey JL (2010) Trophic relationships of breeding red-necked Grebes (Podiceps grisegena) on wetlands with and without fish in the Aspen Parkland. Can J Zool 88:186-194

Michener RH, Schell DM (1994) Stable isotopes as tracers in marine aquatic food webs. In: Lajtha K, Michener RH (eds) Stable isotopes in ecology and environmental science. Blackwell Scientific Publications, Oxford, UK, pp 138-157

Minagawa M, Wada E (1984) Stepwise enrichment of ${ }^{15} \mathrm{~N}$ along food chains: further evidence and the relation between $\delta^{15} \mathrm{~N}$ and animal age. Geochim Cosmochim Acta 48:1135-1140

Mizutani H, Fukuda M, Kabaya Y (1992) $\delta^{13} \mathrm{C}$ and $\delta^{15} \mathrm{~N}$ enrichment factors of feathers of 11 species of adult birds. Ecology 73:1391-1395

Moreno R, Jover L, Munilla I, Velando A, Sanpera C (2010) A threeisotope approach to disentangling the diet of a generalist consumer: the yellow-legged gull in northwest Spain. Mar Biol 157:545-553

Morkūnė R, Lesutienė J, Barisevičiūtė R, Morkūnas J, Gasiūnaitė ZR (2016) Food sources of wintering piscivorous waterbirds in coastal waters: A triple stable isotope approach for the southeastern Baltic Sea. Estuar Coast Shelf Sci 171:41-50

Morrison RIG, Hobson KA (2004) Use of body stores in shorebirds after arrival on higharctic breeding grounds. Auk 121:333-344

Newbrey JL, Paszkowski CA, Gingras BA (2012) Trophic relationships of two species of grebe on a prairie lake based on stable isotope analysis. Hydrobiologia 697:73-84

Oppel S, Powell AN, O’Brien DM (2010) King eiders use an income strategy for egg production: a case study for incorporating individual dietary variation into nutrient allocation research. Oecologia 164:1-12

Parnell AC, Inger R, Bearhop S, Jackson AL (2010) Source partitioning using stable isotopes: coping with too much variation. PLoS ONE 5(3):e9672

Paszkowski CA, Gingras BA, Wilcox K, Klatt PH, Tonn WM (2004) Trophic relations of the Red-necked Grebe on lakes in the western boreal forest: A stable-isotope analysis. Condor 106:638-651

Peig J, Green AJ (2009) New perspectives for estimating body condition from mass/length data: The scaled mass index as an alternative method. Oikos 118:1883-1891
Peterson BJ, Fry B (1987) Stable isotopes in ecosystem studies. Ann Rev Ecol Syst 18:293-320

Piersma T (1988) The annual moult cycle of great crested grebes. Ardea 76:82-95

Pinnegar JK, Polunin NVC (1999) Differential fractionation of $\delta^{13} \mathrm{C}$ and $\delta^{15} \mathrm{~N}$ among fish tissues: implications for the study of trophic interactions. Funct Ecol 13:225-231

Post D, Layman C, Arrington DA, Takimoto G, Quattrochi J, Montaña C (2007) Getting to the fat of the matter: models, methods and assumptions for dealing with lipids in stable isotope analyses. Oecologia 152:179-189

Schmaltz LE, Loonstra AJ, Wymenga E, Hobson KA, Piersma T (2018) Quantifying the non-breeding provenance of staging Ruffs, Philomachus pugnax, using stable isotope analysis of different tissues. J Ornithol 159:191-203

Schmutz JA, Hobson KA, Morse JA (2006) An isotopic assessment of protein from diet and endogenous stores: effects on egg production and incubation behavior of geese. Ardea 94:385-397

Sénéchal É, Bêty J, Gilchrist HG, Hobson KA, Jamieson SE (2011) Do purely capital layers exist among flying birds? Evidence of exogenous contribution to Arctic-nesting Common Eider eggs. Oecologia 165:593-604

Skov H, Heinänen S, Žydelis R, Bellebaum J, Bzoma S, Dagys M, Durinck J, Garthe S, Grishanov G, Hario M, Kieckbusch JJ, Kube J, Kuresoo A, Larsson K, Luigujõe L, Meissner W, Nehls HW, Nilsson L, Petersen IK, Mikkola-Roos M, Pihl S, Sonntag N, Stock A, Stipniece A, Wahl J (2011) Waterbird populations and pressures in the Baltic Sea. TemaNord 550

Sorensen MC, Hipfner JM, Kyser TK, Norris DR (2009) Carry-over effects in a Pacific seabird: stable isotope evidence that nonbreeding diet quality influences reproductive success. J Anim Ecol 78:460-467

Sydeman WJ, Penniman JF, Penniman TM, Pyle P, Ainley DG (1991) Breeding performance in the Western Gull: effects of parental age, timing of breeding and year in relation to food supply. J Anim Ecol 60:135-149

Tieszen LL, Boutton TW, Tesdahl KG, Slade NA (1983) Fractionation and turnover of stable carbon isotopes in animal tissues, implications for $\delta^{13} \mathrm{C}$ analysis of diet. Oecologia 57:32-37

Vander Zanden MJ, Rasmussen JB (1999) Primary consumer $\delta^{13} \mathrm{C}$ and $\delta^{15} \mathrm{~N}$ and the trophic position of aquatic consumers. Ecology 80:1395-1404

Vanderklift MA, Ponsard S (2003) Sources of variation in consumer diet $\delta^{15} \mathrm{~N}$ enrichment: a meta-analysis. Oecologia 136:169-182

Vlug JJ (2018) The Red-necked Grebe - a monograph of a vociferous inhabitant of marshy lakes. Corax 23:1-318

Williams CT, Klaassen M, Barnes BM, Buck CL, Arnold W, Giroud S, Ruf Vetter SG, T, (2017) Seasonal reproductive tactics: annual timing and the capital-to-income breeder continuum. Philos Trans R Soc B 372:20160250

Publisher's Note Springer Nature remains neutral with regard to jurisdictional claims in published maps and institutional affiliations. 


\section{Affiliations}

\section{Janusz Kloskowski ${ }^{1}$ (D) Andrzej Trembaczowski ${ }^{2} \cdot$ Maciej Filipiuk $^{3}$}

$\triangle$ Janusz Kloskowski janusz6kl@gmail.com

Andrzej Trembaczowski atrem@tytan.umcs.lublin.pl

Maciej Filipiuk

maciejfilipiuk@o2.pl

1 Institute of Zoology, Poznań University of Life Sciences, Wojska Polskiego 71C, 60-625 Poznań, Poland
2 Mass Spectrometry Laboratory, Institute of Physics, Maria Curie-Skłodowska University, Plac Marii Curie-Skłodowskiej 1, 20-031 Lublin, Poland

3 Department of Nature Conservation, Institute of Biology and Biochemistry, Maria Curie-Skłodowska University, Akademicka 19, 20-033 Lublin, Poland 